\title{
Biopaliwa w zrównoważonej biogospodarce
}

\author{
Ewa Krasuska, Magdalena Rogulska \\ Przemysłowy Instytut Motoryzacji \\ Zakład Paliw Płynnych i Biogospodarki \\ ul. Jagiellońska 55, 03-301 Warszawa, e.krasuska@pimot.eu
}

\section{Streszczenie}

Biopaliwa transportowe uzyskały wsparcie polityczne i początkowo miały pozytywny odbiór społeczny. Z czasem negatywne skutki uboczne stały się źródłem kwestionowania roli biopaliw w zrównoważonym rozwoju gospodarczym. Biopaliwa zaawansowane wytworzone z zasobów biomasy, które nie powodują konkurencji z produkcją żywności i pasz, mają istotną rolę w biogospodarce. Powinny być wytwarzane głównie w oparciu o odpady i pozostałości. Biorafinerie jako miejsce wytwarzania bioproduktów i biopaliw będą odgrywały kluczową rolę w produkcji przemysłowej w zrównoważonej biogospodarce.

\section{Słowa kluczowe}

biopaliwa, bioenergia, biorafineria, biogospodarka, kryteria zrównoważonego rozwoju

\section{Wprowadzenie}

Biopaliwa transportowe jako nośnik energii ze źródeł odnawialnych (OZE) w sektorze transportu uzyskały wsparcie polityczne i początkowo miały pozytywny odbiór społeczny. Z założenia miały przyczynić się do realizacji idei zrównoważonego rozwoju (Borychowski 2014). Stymulowany celami politycznymi i ekonomicznymi mechanizmami wsparcia, sektor produkcji i wykorzystania biopaliw w Europie i w Polsce rozwijał się dynamicznie. Jednak z biegiem czasu negatywne skutki uboczne produkcji biopaliw stały się podstawą kwestionowania roli biopaliw w zrównoważonym i odpowiedzialnym rozwoju gospodarczym.

Pojęcie rozwoju zrównoważonego ewaluowało od roku 1987, kiedy zostało użyte po raz pierwszy przez Komisję Bruntland.
Od tego czasu powstało wiele definicji na potrzeby nauk ekonomicznych, biologicznych, urbanistyki, itp. Można uznać, że cechą wspólną jest dążenie do zrównoważenia podstawowych elementów systemu kształtującego przyszłość społeczności ludzkiej na Ziemi: ekonomicznego, środowiskowego i społecznego. Zrównoważony rozwój nie jest wymiarem statycznym, lecz bardzo dynamicznym, zmieniający się w przestrzeni oraz w czasie (Wellisch et al. 2010: 276).

W Strategii Europa 2020 będącej 10-letnią strategią Unii Europejskiej (UE) na rzecz zatrudnienia i wzrostu gospodarczego, zrównoważony rozwój uznano za nadrzędną zasadę transformacji w kierunku gospodarki efektywnie korzystającej z zasobów, bardziej przyjaznej dla środowiska i bardziej konkurencyjnej (A). W tym kontekście 
na szczególną uwagę zasługuje przyjęta w 2012 r. przez Komisję Europejską strategia na rzecz zrównoważonego wykorzystania zasobów odnawialnych w gospodarce pod nazwą „Innowacje dla zrównoważonego wzrostu: biogospodarka dla Europy" (B). Biogospodarka obejmuje produkcję odnawialnych zasobów pochodzenia biologicznego na lądzie i w morzach oraz wykorzystanie tych zasobów i strumieni odpadowych do wytworzenia produktów o wartości dodanej, takich jak żywność, pasze, bioprodukty, biomateriały i bioenergia (B: 9). Europejska strategia biogospodarki stanowi wszechstronną odpowiedź na wyzwania w zakresie ograniczonych zasobów naturalnych, zależności od paliw kopalnych, negatywnego oddziaływania gospodarki na środowisko, zmian klimatu, zaopatrzenia w żywność i energię, z którymi mierzy się obecnie Europa i świat.

Celem niniejszego opracowania jest określenie roli biopaliw transportowych $\mathrm{w}$ innowacyjnej i zrównoważonej biogospodarce. Podstawą źródłową opracowania są dokumenty legislacyjne i literatura przedmiotu.

\section{Biopaliwa konwencjonalne versus biopaliwa zaawansowane}

\subsection{Polityka promocji biopaliw}

Wykorzystanie biopaliw, czyli paliw z przetwarzania biomasy, stanowi w UE kluczowy element realizacji polityki zwiększenia udziału energii z OZE w transporcie. Jako substytut paliw produkowanych z ropy naftowej, biopaliwa ciekłe i gazowe mają umożliwić dekarbonizację sektora transportu, co w konsekwencji prowadzi do ograniczenia emisji gazów cieplarnianych (GHG) do atmosfery i wpisuje się w strategię przeciwdziałania zmianom klimatu. Ponadto dywersyfikacja paliw sprzyja zwiększeniu bezpieczeństwa energetycznego Europy, w sytuacji gdy sektor transportu jest silnie uzależniony od importowanej ropy naftowej. Jednocześnie produkcja biopaliw stwarza możliwość dywersyfikacji działalności na obszarach wiejskich przez stworzenie nowych rynków zbytu na surowce rolnicze.
Polityka promocji biopaliw w UE rozpoczęła się w 2003 r., kiedy w Dyrektywie 2003/3o/WE wprowadzono obowiązek dodatku biopaliw (w polskiej nomenklaturze biokomponentów ${ }^{1}$ ) do paliw wprowadzanych na rynek, tak by do roku 2010 osiągnąć udział 5,75\% wg wartości energetycznej w rynku paliw transportowych (C: art.3 p. 6). W 2009 r. w Dyrektywie 2009/28/WE zdefiniowano obligatoryjny minimalnym cel dla wszystkich krajów członkowskich na poziomie 10\% udziału energii z OZE w transporcie do roku 2020 (D: art.3 p.140/28). W transporcie drogowym obowiązek realizowany jest powszechnie poprzez udział biokomponentów w paliwach ciekłych domieszkę bioetanolu do benzyn (do $5 \%$ lub 10\% obj.) oraz domieszkę estrów metylowych kwasów tłuszczowych do oleju napędowego (do $7 \%$ obj.). Cele na kolejny okres zostały opublikowane dn. 30 listopada $2016 \mathrm{r}$. w projekcie nowelizacji Dyrektywy 2009/28/ WE stanowiącej element tzw. Pakietu Zimowego (E; Web-01). Energia z OZE powinna osiągnąć poziom $27 \% \mathrm{w}$ końcowym zużyciu energii w UE do 2030 r. Dla transportu wyodrębniono cel szczegółowy na poziomie $1,5 \%$ w $2021 \mathrm{r}$. i wzrastający do $6,8 \% \mathrm{w} 2030 \mathrm{r}$. w odniesieniu do całkowitej ilości paliw wprowadzanych na rynek (wg wartości energetycznej) (E: art.25 p.10o-102).

Jasno zdefiniowane cele oraz wsparcie finansowe ze źródeł publicznych zaowocowały dynamicznym rozwojem rynku biopaliw. W 2014 r. biopaliwa stanowiły 4,9\% w rynku transportu drogowego w UE i od tamtej pory ich udział waha się, co związane jest z szeroką debatą publiczną nad dalsza rolą biopaliw (EBTP SRIA 2016: 2). W Polsce udział energii z OZE w transporcie, co w praktyce odpowiada wykorzystaniu biokomponentów (głównie bioetanolu oraz estrów metylowych kwasów tłuszczowych) dynamicznie wzrastał od 2008 r. osiągając

1 Listę biokomponentów dopuszczalnych do stosowania w Polsce podaje art. 2 ustawy o biokomponentach i biopaliwach z dn. 25 sierpnia $2006 \mathrm{r}$. (Dz.U. 2006 Nr 169 poz. 1199 tj. Dz.U. 2017 poz. 285) 


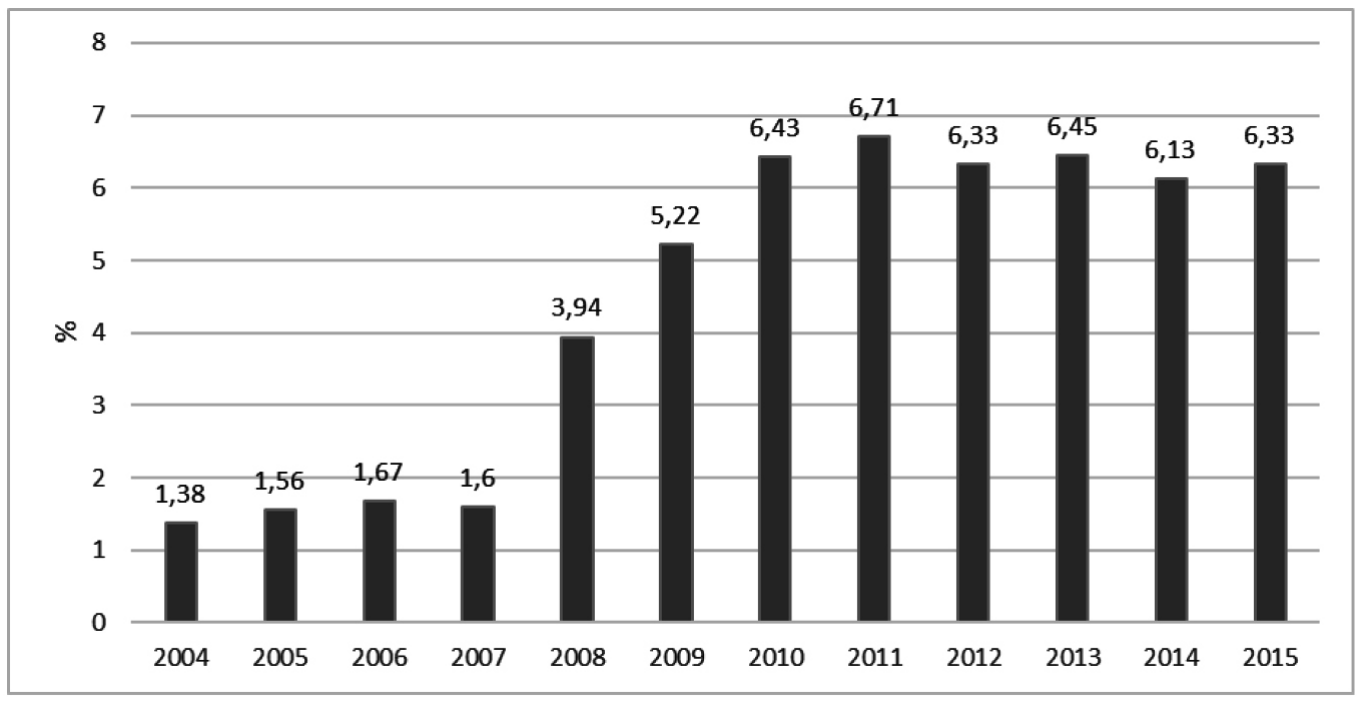

Rys. 1. Procentowy udział energii ze źródeł odnawialnych w sektorze transportu w Polsce w latach 2004-2015 (Źródło: GUS 2015).

poziom 6,71\% w 2011 r., w ostatnich latach udział ten był nieznacznie niższy (rys. 1). (GUS 2015: 51).

\subsection{Krytyka biopaliw konwencjonalnych}

Dotychczasowy rozwój produkcji i wykorzystania biopaliw związany jest z szeregiem negatywnych skutków ubocznych, co ma odzwierciedlenie w szerokiej i krytycznej debacie wokół polityki promowania biopaliw jaka toczy się od 2012 r. Biopaliwa oskarżane są o konkurowanie o surowce z produkcją żywności, co ma przede wszystkim wymiar etyczny. Rozwój sektora biopaliw konwencjonalnych, czyli wytworzonych z surowców rolnych (roślin skrobiowych, cukrowych, oleistych) oraz tłuszczy zwierzęcych spowodował zaburzenia dotychczasowego stanu równowagi pomiędzy przeznaczeniem surowców na cele spożywcze oraz przemysłowe (w tym biopaliwowe). Konkurowanie biopaliw z produkcją żywności odbywa się bezpośrednio o surowiec bądź o grunty niezbędne do uprawy surowca.

W wielu przypadkach rosnące zapotrzebowanie na biopaliwa doprowadziło do przekształcenia terenów cennych przyrodniczo w uprawy przemysłowe. Dotyczy to głównie krajów rozwijających się, w których lokalizowana jest produkcja na potrzeby Europy i innych krajów wysoko rozwiniętych. Skutkiem jest utrata cennych ekosystemów (lasów pierwotnych, torfowisk itp.) z ich różnorodnością biologiczną oraz uwolnienie do atmosfery znaczących ilości $\mathrm{CO}_{2}$ z zasobów węgla organicznego związanego w glebie. Emisja ta łączy się z produkcją biopaliw, jeśli surowce pozyskane $\mathrm{z}$ tych terenów zostały wykorzystane przez sektor biopaliwowy. Obok bezpośredniej zmiany użytkowania gruntów zdefiniowano także zjawisko pośredniej zmiany użytkowania gruntów, tzw. ILUC ( $\mathrm{z}$ ang. indirect land use change). Rosnące zapotrzebowanie na biopaliwa powoduje wzrost globalnego popytu na surowce rolnicze, co w konsekwencji prowadzi do pozyskiwania w różnych częściach świata nowych terenów pod produkcję żywności kosztem obszarów cennych przyrodniczo i bogatych w zasoby węgla organicznego. Emisja GHG związana z ILUC może być także przypisana do sektora biopaliw.

Ponadto podkreśla się niewystarczającą rolę biopaliw w ograniczeniu emisji GHG w odniesieniu do ich kopalnych odpowiedników (benzyny lub oleju napędowego) i tym 


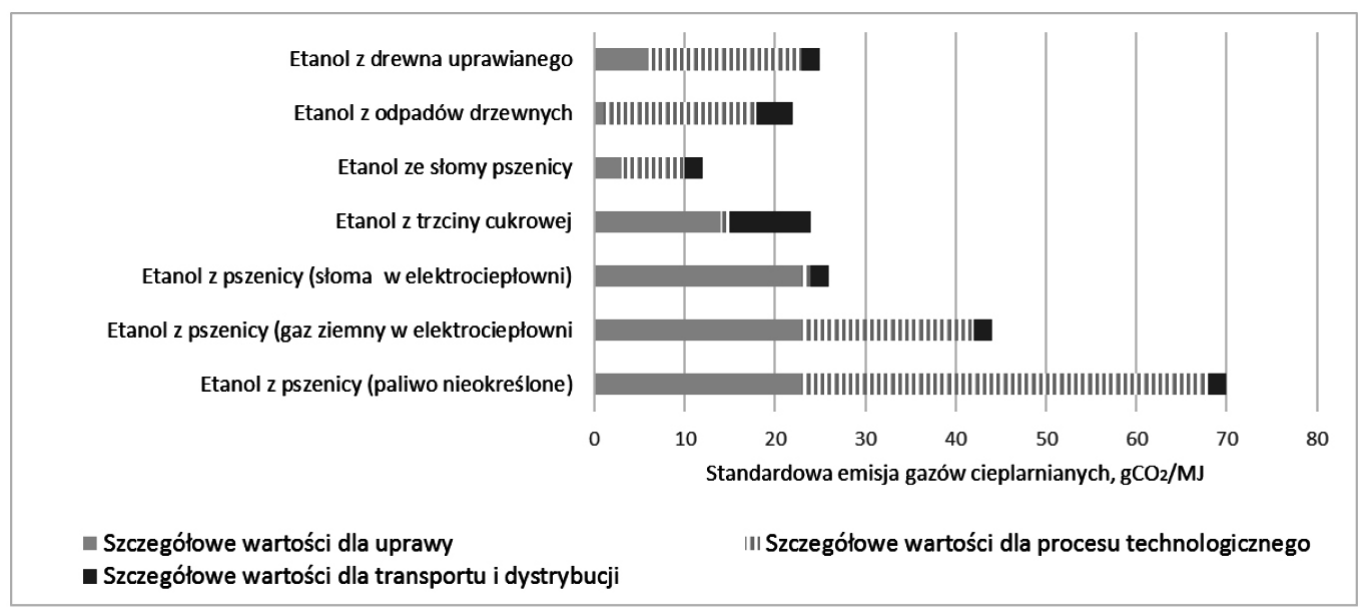

Rys. 2. Standardowa emisja gazów cieplarnianych z produkcji etanolu wytworzonego z różnych surowców oraz z wykorzystaniem różnych procesów technologicznych (paliwo technologiczne podano w nawiasie) (Źródło: D: Załącznik V, p. 140/52-59).

samym kwestionuje się rolę biopaliw w przeciwdziałaniu zmianom klimatu. W dużej mierze związane jest to $\mathrm{z}$ nakładami energetycznymi na etapie produkcji surowca rolnego oraz wspomnianą emisją związaną $\mathrm{z}$ bezpośrednią lub pośrednią zmianą użytkowania gruntów. Należy zaznaczyć, że poziom redukcji emisji GHG jest bardzo różny dla biopaliw ze względu na zastosowany surowiec, proces technologiczny i stosowane w nim źródło energii (paliwo technologiczne). Na rys. 2 przedstawiono emisję standardową ${ }^{2} \mathrm{z}$ produkcji etanolu uwzględniając różne surowce oraz paliwa technologiczne (D: Załącznik V, p. 140/52-59). Bardzo efektywne w zakresie ograniczenia emisji $\mathrm{GHG}^{3}$ są biopaliwa wytwarzane z pozostałości i odpadów, oraz te przy produkcji których wykorzystuje się energię pozyskaną z OZE.

2 Emisja standardowa podana jest jako wartość odniesienia w Dyrektywie 2009/28/WE, Załącznik V, p. 140/52-59.

3 Ograniczenie emisji gazów cieplarnianych z produkcji biopaliw oblicza się dzieląc różnicę całkowitej emisji związanej z odpowiednikiem kopalnym i całkowitej emisji związanej z biopaliwem przez całkowitą emisję związaną $\mathrm{z}$ odpowiednikiem kopalnym.
W wymiarze ekonomicznym, należy zaznaczyć, że rozwój europejskiego rynku biopaliw silnie opiera się na importowanych z odległych części świata surowcach (olej palmowy i sojowy, etanol z trzciny cukrowej), co podtrzymuje dużą zależność importową sektora transportu. Z importem surowców łączy się zjawisko oddzielenia (dystans przestrzenny) konsumpcji biopaliw w Europie od obciążeń związanych z produkcją surowca w uboższych częściach świata. Przekształcanie gruntów pod plantacje przemysłowe wielokrotnie wiązało się z ogromnymi kosztami dla społeczności lokalnych: utrata dostępu do cennych ekosystemów przyrodniczych, wywłaszczenia i przesiedlenia, organicznie lokalnej produkcji żywności, wzrost cen surowców rolnych na lokalnych rynkach (Mohr i Raman 2013: 116-119). Należy zaznaczyć, że obok biopaliw podobne skutki uboczne obserwuje się w przypadku innych wielkoskalowych upraw przemysłowych lokalizowanych poza Europą.

\subsection{Kryteria zrównoważonego rozwoju w odniesieniu do biopaliw}

Aby zapobiegać negatywnym wpływom biopaliw na środowisko, zdefiniowano kryteria zrównoważonego rozwoju dla biopaliw 


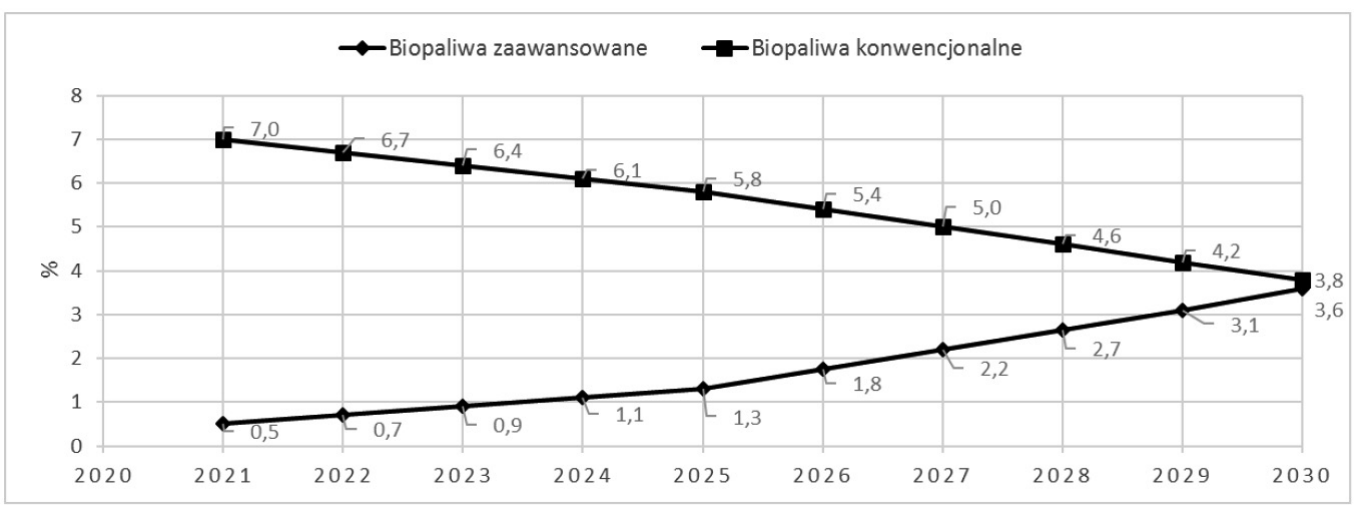

Rys. 3. Minimalny obowiązkowy udział biopaliw zaawansowanych w rynku paliw dla transportu do roku 2030 oraz maksymalny dopuszczalny udział biopaliw konwencjonalnych (wg wartości energetycznej) (Źródło: G: Annex X, p. 99-100).

i biopłynów4. W Dyrektywie 2009/28/WE ustalono kryteria, które muszą spełnić biopaliwa wprowadzone na rynek UE, aby mogły uzyskać wsparcie publiczne oraz być zaliczane do realizacji celów krajowych dotyczących energii z OZE w transporcie (D: art. 17 p. 14/36-38). W praktyce weryfikowane jest to przez obowiązek certyfikacji biopaliw na kryteria zrównoważonego rozwoju. Kryteria te odnoszą się do wykluczenia z produkcji biopaliw surowców uprawianych na gruntach, które powstały w wyniku konwersji terenów o wysokiej różnorodności biologicznej (lasy pierwotne i inne obszary leśne, obszary ochrony przyrody, obszary trawiaste) oraz terenów zasobnych w pierwiastek węgla (obszary podmokłe, torfowiska). Jednocześnie biopaliwa muszą osiągać minimalne poziomy ograniczania emisji GHG w cyklu życia biopaliw (z ang. life cycle) w odniesieniu do odpowiednika kopalnego. Emisja GHG w cyklu życia biopaliw obejmuje cały łańcuch wytwórczy, w którym można wymienić etapy, takie jak: uprawa lub pozyskanie surowca, proces technologiczny wytwarzania biopaliwa oraz transport i dystrybucję. Wymagane ograniczenia emisji GHG dla biopaliw zostały aktualizowane w 2015 r. poprzez Dyrektywę 2015/1513 i wynoszą 60\%

4 Ciekłych lub gazowych paliw z biomasy. w przypadku biopaliw wyprodukowanych w instalacjach, które rozpoczęły działalność po dn. 5 października $2015 \mathrm{r}$. W przypadku instalacji, które działały w dn. 5 października 2015 r. lub wcześniej ograniczenie emisji GHG wynosi co najmniej 35\% do 31 grudnia 2017 r. i co najmniej 50\% od 1 stycznia 2018 r. (F: art. 2 p. 239/17).

W 2015 roku poprzez Dyrektywę 2015/1513 Komisja Europejska wprowadziła także ograniczenie udziału rynkowego biopaliw konwencjonalnych, dodatkowo wprowadzając obowiązek raportowania emisji z ILUC. Dla biopaliw zaawansowanych wytworzonych z surowców innych niż spożywcze wprowadzono wskaźnik o,5\% udziału w rynku paliw do roku 2020 (F: art. 3 p. 239/23). Cele te zostały potwierdzone w opublikowanym w 2016 r. projekcie nowelizacji Dyrektywy 2009/28/WE. Ustalono dla kolejnych lat obowiązkowy minimalny udział procentowy w rynku dla biopaliw zaawansowanych, jednocześnie ustalając ograniczenie udziału w rynku dla biopaliw konwencjonalnych (rys. 3) (E: art. 25 p.10o-101; E: art. 7 p.79). Po roku 2020 biopaliwa konwencjonalne nie będą mogły uzyskać wsparcia publicznego.

Należy podkreślić, że sektor biopaliw jako pierwszy spośród produkcji przemysłowej został objęty obowiązkowym systemem weryfikacji na kryteria zrównoważonego rozwoju. 


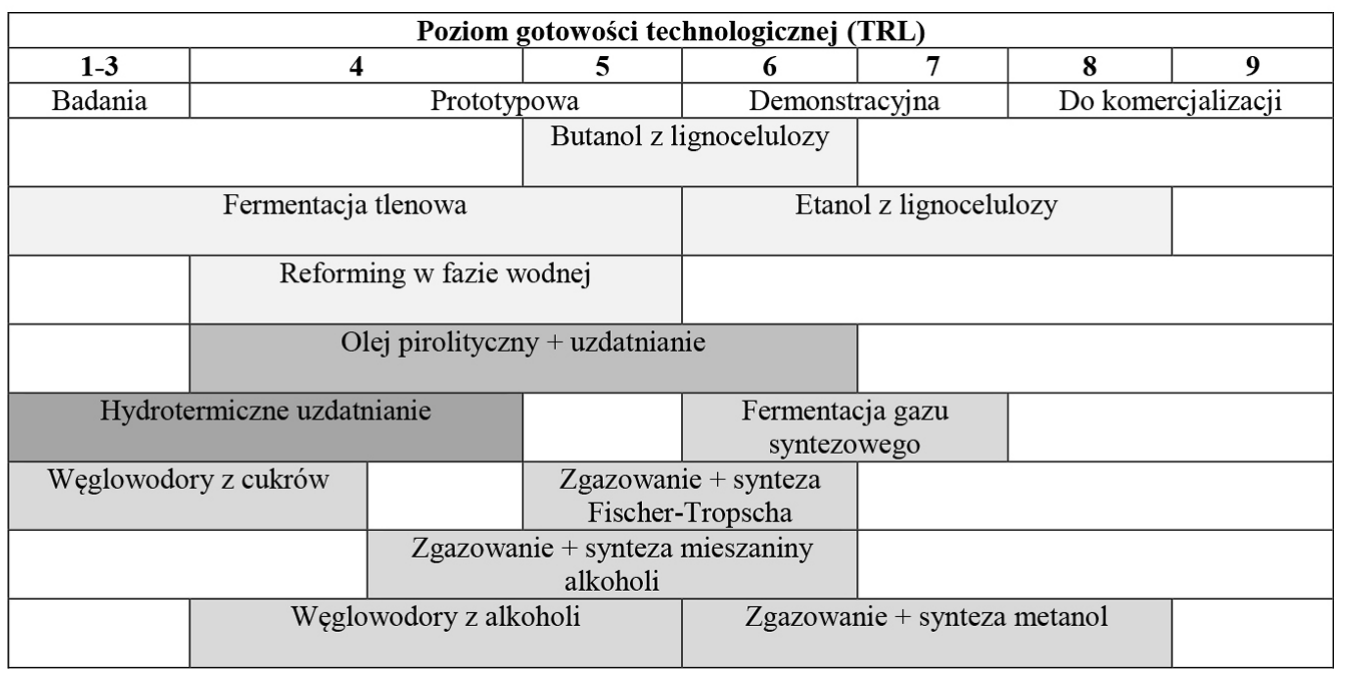

Rys. 4. Poziomy gotowości technologicznej różnych technologii produkcji biopaliw zaawansowanych. (Źródło: IRENA 2016: 5).

\subsection{Biopaliwa zaawansowane}

Alternatywę dla biopaliw konwencjonalnych stanowią między innymi biopaliwa zaawansowane wytwarzane przy zastosowaniu innowacyjnych procesów technologicznych z zasobów biomasy, które nie powodują konkurencji z produkcją żywności i pasz. Chodzi tu o zasoby biomasy lignocelulozowej, pozostałości i odpady oraz inną biomasę nierolniczą, w tym algi i mikroorganizmy (surowce zdefiniowane w Załączniku IX, cz. A, projektu nowelizacji Dyrektywy 2009/28/ WE) (G: zał. IX p. 98).

Gotowość technologii wytwarzania biopaliw zaawansowanych jest nadal niska. Na rys. 4. przedstawiono klasyfikację poszczególnych technologii biopaliw zaawansowanych ze względu na ich gotowość do komercjalizacji wg poziomów TRL (z ang. technologu readiness level). Dotychczas tylko dla dwóch technologii uruchomiono produkcję w skali komercyjnej - produkcja etanolu z biomasy lignocelulozowej oraz produkcja metanolu poprzez zgazowanie biomasy. W odniesieniu do paliw zaawansowanych, których technologia jest mniej dojrzała, konieczne są dalsze badania i większe wsparcie. Łącznie w Europie w skali komercyjnej działa 9 instalacji oraz $7 \mathrm{w}$ demonstracyjnej (IRENA, 2016: 7). Wskazuje to na bardzo wczesny etap rozwoju sektora produkcji biopaliw zaawansowanych, który obecnie nie jest w stanie zaspokoić potrzeb rynkowych. Największa możliwość szybkiej komercjalizacji dostrzega się w następujących technologiach: fermentacja lignocelulozy do etanolu, fermentacja gazu syntezowego, synteza mieszaniny alkoholi, synteza Fischer-Tropscha oraz uzdatnianie oleju pirolitycznego (IRENA 2016: 6).

Szybkie tempo rozwoju sektora biopaliw konwencjonalnych sprawiło, że wielu niezamierzonym negatywnym efektom ubocznym nie udało się zapobiec. Dlatego wobec biopaliw zaawansowanych oczekuje się poprawy wizerunku w wymiarze społecznym, ekonomicznym, etycznym, ekologicznym i politycznym (Mohr i Raman, 2013: 115). Istotne będą skutki ewentualnego zastosowania roślin genetycznie modyfikowanych jako surowca do produkcji biopaliw. Kluczowa dla zapewnienia zrównoważonego charakteru biopaliw zaawansowanych będzie także skala produkcji i zakres powiązanych z nią oddziaływań. 


\section{Biorafineria jako miejsce wytwarzania biopaliw i bioproduktów}

\subsection{Optymalne wykorzystanie zasobów w biogospodarce}

Biogospodarka to sektor gospodarki obejmujący tradycyjne gałęzie przemysłu bazujące na zasobach biomasy. Jest to przede wszystkim przemysł spożywczy, tytoniowy, celulozowo-papierniczy, które w 100\% bazują za zasobach biomasy. Inne gałęzie przemysłu zaliczane do biogospodarki to: tekstylny, odzieżowy, drzewny, meblowy, chemiczny, kosmetyczny, farmaceutyczny, gumowy, materiałów konstrukcyjnych, paliwowy i energetyczny. W konkurencyjnej i zrównoważonej biogospodarce poprzez innowacje będące wynikiem badań - głównie z zakresu biotechnologii - możliwe będzie wprowadzenie nowych produktów, technik produkcyjnych oraz wzrost efektywności współzależnych łańcuchów wartości (Gołębiewski 2013: 5). Surowcem pozostaje biomasa, jednak kluczowa jest odpowiedź na wyzwania takie jak: zrównoważona produkcja biomasy, efektywność wykorzystania biomasy oraz efekt skali w odniesieniu do mobilizowania zasobów (Scarlat et al. 2015: 5).

W odniesieniu do zastosowań na cele energetyczne i paliwowe definicja biomasy została podana w Dyrektywie 2009/28/WE. Biomasa oznacza „ulegającą biodegradacji część produktów, odpadów lub pozostałości pochodzenia biologicznego z rolnictwa (...), leśnictwa i związanych działów przemysłu, w tym rybołówstwa i akwakultury, a także ulegającą biodegradacji część odpadów przemysłowych i miejskich" (D: art. 2 p. 140/27). W odniesieniu do szerokiego spektrum produktów otrzymywanych w zrównoważonej biogospodarce, konieczne jest przewartościowanie podejścia do dostępnej bazy surowcowej (Wellisch et al. 2010: 276). Podstawę produkcji biopaliw i bioenergii powinny stanowić wtórne zasoby biomasy, czyli pozostałości i odpady z różnych procesów produkcji i przetwarzania oraz odpady pokonsumpcyjne. Zasoby biomasy pierwotnej, czyli biomasa pozyskana bezpośrednio z rolnictwa, leśnictwa lub zasobów wodnych, powinny być wykorzystywane głównie do produkcji wyrobów o wyższej wartości dodanej, czyli bioproduktów i biomateriałów (IEA Bioenergy 2013: 10). Takie podejście podyktowane jest zasadą optymalnego wykorzystania dostępnych zasobów, jest także uwarunkowane ekonomicznie.

Zasoby biomasy muszą być wytwarzane w sposób zrównoważony oraz wykorzystane optymalnie i efektywnie, tak by uzyskać jak najwyższą sumaryczną wartość dodaną produktów końcowych. Założenie to w praktyce realizowane będzie poprzez wdrożenie zasady wykorzystania kaskadowego zasobów, w tym waloryzację powstających odpadów i pozostałości. Kaskadowe wykorzystanie oznacza wykorzystanie, użycie ponowne, poddanie recyklingowi, a na końcu przetworzenie w energię (H, p. 39). Jeśli jest opłacalne ekonomicznie i wykonalne technicznie, jest optymalnym sposobem wykorzystania surowca w gospodarce.

Innym procesem pozwalający zwiększyć efektywność wykorzystania zasobów jest rafinacja (van Ree 2016: 2). Rafinacja odnosi się do zakładu przemysłowego, czyli biorafinerii, w której zachodzą procesy wielokierunkowego przetwarzania biomasy w celu uzyskania wielu różnych wartościowych produktów rynkowych. Optymalizacja zużycia biomasy może być także realizowana poprzez efekt synergii w różnych gałęziach przemysłu w biogospodarce.

Biogospodarke oparta na koncepcji kaskadowego wykorzystania zasobów biomasy, rafinacji produktów oraz waloryzacji odpadów i pozostałości można doskonale opisać poprzez piramidę wartości (rys.5) (van Ree 2016: 6). Obrazuje ona relacje dotyczące wartości rynkowej i ilości wytwarzanych produktów. Na górze piramidy znajdują się produkty o największej wartości (uzyskujące wysokie ceny rynkowe), w ujęciu ilościowym jest ich jednak stosunkowo niewiele, ponieważ występują w niskiej koncentracji w biomasie lub też otrzymywane są w wyniku skomplikowanych procesów 


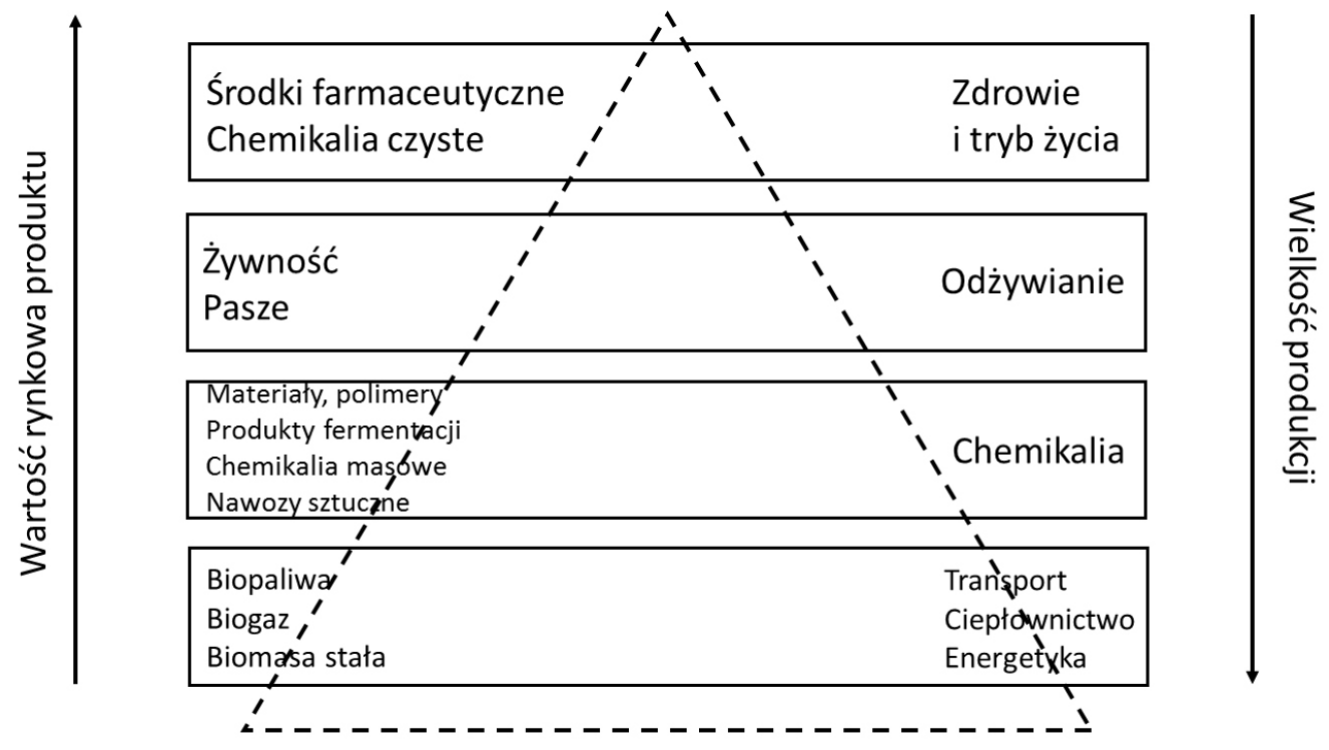

Rys. 5. Piramida opisująca relację wartość rynkowa versus ilość dla różnych produktów otrzymywanych z biomasy w biogospodarce (Źródło: van Ree 2016: 6).

technologicznych. Należą do nich środki farmaceutyczne, bioskładniki odżywcze, oraz chemikalia o dużej czystości. Poniżej znajdują się wartościowe produkty wytwarzane w większych ilościach, takie jak żywność, pasze, chemikalia, nawozy, biomateriały. U podstawy piramidy umiejscowione są paliwa i energia, które wytwarzane są w największych ilościach, jednak mają to być produkty relatywnie tanie, pozyskiwane głównie z pozostałości i odpadów.

\subsection{Biorafineria jako zintegrowany układ przetwarzania biomasy}

Biorafineria jest zintegrowanym układem (procesów i urządzeń), w którym dokonuje się wielokierunkowa i kompleksowa konwersja biomasy w kierunku wytworzenia wielu produktów rynkowych (żywność, pasze, chemikalia, materiały) oraz energii (paliwa, ciepło i/lub energia elektryczna) (Jungmeier et al. 2013: 2). Koncepcja biorafinerii odpowiada w pewnym sensie istniejącym przetwórniom ropy naftowej, które produkują paliwa i inne produkty (Biernat i Grzelak 2015). Budzianowski (2017: 794) zwraca uwagę, że biorafinerie to układy, które integrują kilka współczesnych gałęzi przemysłu. Ich celem jest realizacja zasady zmaksymalizowania wykorzystania potencjału materiałowego i energetycznego zawartego w biomasie.

Charakterystyka biorafinerii opiera się na określeniu platform, które najczęściej odnoszą się do produktów pośrednich uzyskanych z biomasy lub do różnych koncepcji biorafinerii bądź do produktów końcowych (Jungmeier et al. 2013: 2-3). Przykładowe platformy to: cukrowa, olejowa, biogazowa, gazu syntezowego, oleju pirolitycznego, energii elektrycznej i/lub ciepła. Złożoność biorafinerii wzrasta wraz z rosnącą liczbą platform oraz produktów końcowych. Ogólna koncepcja biorafinerii z uwzględnieniem platform, procesów rafineryjnych oraz produktów końcowych została przedstawiona na rys. 6.

W biorafineriach stosuje się szeroką gamę procesów chemicznych i biochemicznych: hydrolizę chemiczną lub enzymatyczną, dehydratację, fermentację, pirolizę, termiczne odtlenienie i uwodornienie itd. Po obróbce wstępnej biomasa poddana jest procesom rafinacji wstępnej w wyniku których powstają 


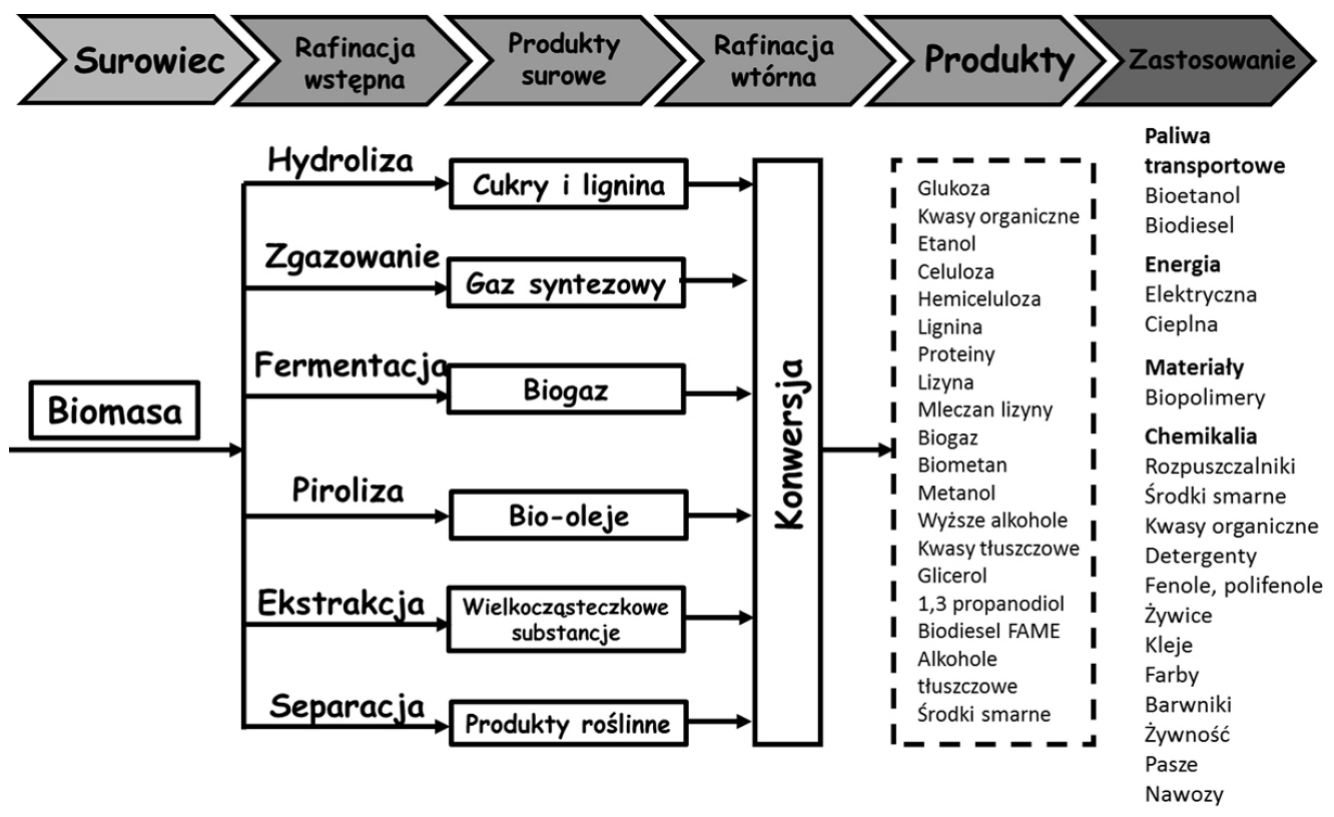

Rys. 6. Ogólny schemat biorafineri (Źródło: Szwach i Kulesza 2014: 894).

półprodukty, następnie w procesach rafinacji wtórnej otrzymywane są produkty końcowe. Najważniejszymi produktami chemicznymi i materiałami otrzymywanymi w biorafineriach są: substancje chemiczne (chemikalia specjalnego zastosowania, bazy surowcowe, produkty masowe), kwasy organiczne, polimery i żywice (tworzywa sztuczne na bazie skrobi, żywice fenolowe, żywice furanowe), biomateriały (panele z drewna, masy celulozowej, papieru, celulozy), żywność, pasze, nawozy (Szwach i Kulesza, 2014; Owczuk et al. 2015).

Istniejące biorafinerie są nieliczne, a większość instalacji działa w skali pilotażowej. Bariera pozostaje dla wielu technologii niski stopień gotowości do komercjalizacji, zarówno w odniesieniu do wytwarzania bioproduktów, jak również biopaliw zawansowanych (IEA Bioenergy 2014: 5). Biorafinerie mogą powstawać w bardzo różnych formach, rozmiarach i konfiguracjach odpowiadając zapotrzebowaniu na konkretne produkty rynkowe, dostępności biomasy, infrastruktury, know-how (Wellisch in in. 2010: 276). Biorafinerie właściwie zaprojektowane i zarządzane mogą stanowić narzędzie realizacji idei zrównoważonego rozwoju w odniesieniu do produkcji przemysłowej.

\subsection{Przykłady biorafinerii paliwowych}

Ze względu na produkty finalne biorafinerie można podzielić na biorafinerie paliwowe, które produkują głównie biopaliwa transportowe i energię, oraz biorafinerie produktowe wytwarzające wiele produktów, przy czym priorytetem jest uzyskanie z biomasy produktów o najwyższej wartości ekonomicznej (Jungmeier et al. 2013: 2). Podział ten jest umowny i w praktyce może się zacierać.

Najprostszym przykładem biorafinerii paliwowej są zakłady wytwarzające biopaliwa konwencjonalne. Zakład, który produkuje z nasion rzepaku estry metylowe kwasów tłuszczowych stosowane jako dodatek do oleju napędowego, glicerynę oraz paszę (wytłoki rzepakowe) jest biorafinerią 1-platformową (olejową). Innym przykładem jest zakład AGRANA w Pischelsdorf w Austrii, w którym na bazie istniejącego zakładu 


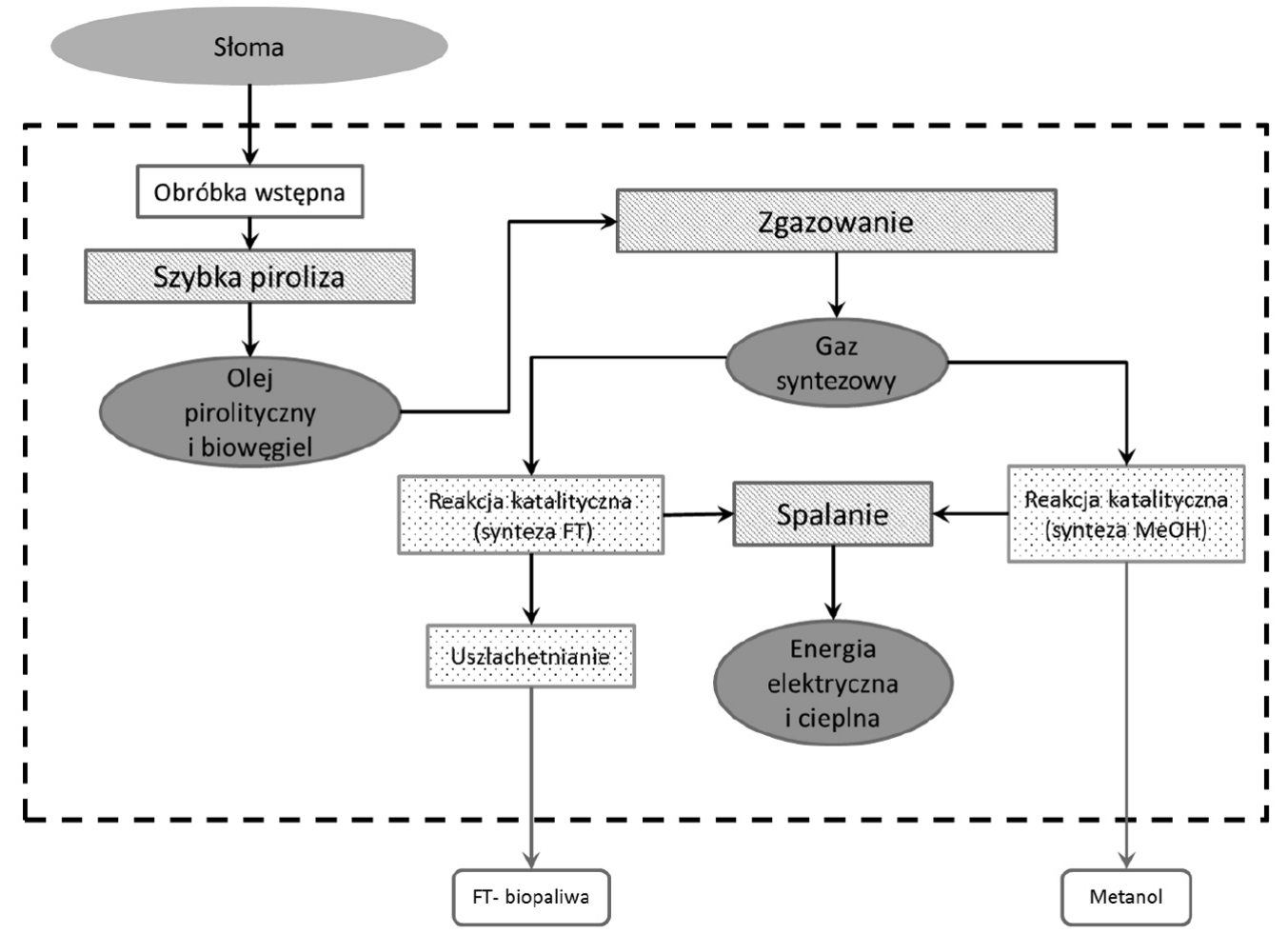

Rys. 7. Koncepcja biorafinerii 3-platformowej w Karlsruhe w Niemczech (Źródło: Jungmeier et al. 2013)

produkującego bioetanol z ziarna zbóż stworzono biorafinerię 2-platformową. Obok bioetanolu produkuje się tam skrobię, gluten, otręby, paszę (suszony zbożowy wywar gorzelniany) oraz wysokiej jakości sprężony $\mathrm{CO}_{2}$ (dla przemysłu spożywczego).

Powyższe przykłady dotyczą produkcji biopaliw konwencjonalnych. Poniżej przedstawiono przykładowe koncepcje biorafinerii, których produktami są biopaliwa zaawansowane. Jednocześnie obok biopaliw pojawiają się inne produkty o wysokiej wartości rynkowej.

Firma SEKAB opracowała koncepcję 3-platformowej biorafinerii, która przetwarza zrębki drewna. Po procesie hydrolizy drewna uzyskiwany jest etanol do celów transportowych. Z ligniny stanowiącej pozostałość po produkcji etanolu mogą być produkowane fenole oraz energia elektryczna i ciepło w układzie skojarzonym. W oparciu o tę koncepcję działa instalacja w Ornskoldsvik w Szwecji, która produkuje bioetanol oraz energię elektryczną i ciepło.

Instytut Technologiczny w Karlsruhe w Niemczech opracował koncepcję biorafinerii 3-platformowej (olej pirolityczny, gaz syntezowy, energia elektryczna i ciepło) (rys. 7), w której surowcem jest słoma zbożowa. Słoma przetwarzana jest na półprodukt - olej pirolityczny w kilku zakładach zlokalizowanych blisko bazy surowcowej. Następnie mieszanina oleju pirolitycznego oraz biowęgla jest transportowana do centralnego zakładu, w którym uzyskuje się gaz syntezowy. W kolejnym kroku procesy technologiczne przebiegają dwutorowo - otrzymywane jest biopaliwo syntetyczne do celów transportowych (synteza Fisher-Tropscha) oraz metanol dla przemysłu chemicznego. Pozostałości i odpady będą wykorzystywane na miejscu do produkcji energii i ciepła. Obecnie w Karlsruhe działa pilotażowa instalacja do szybkiej pirolizy biomasy. 


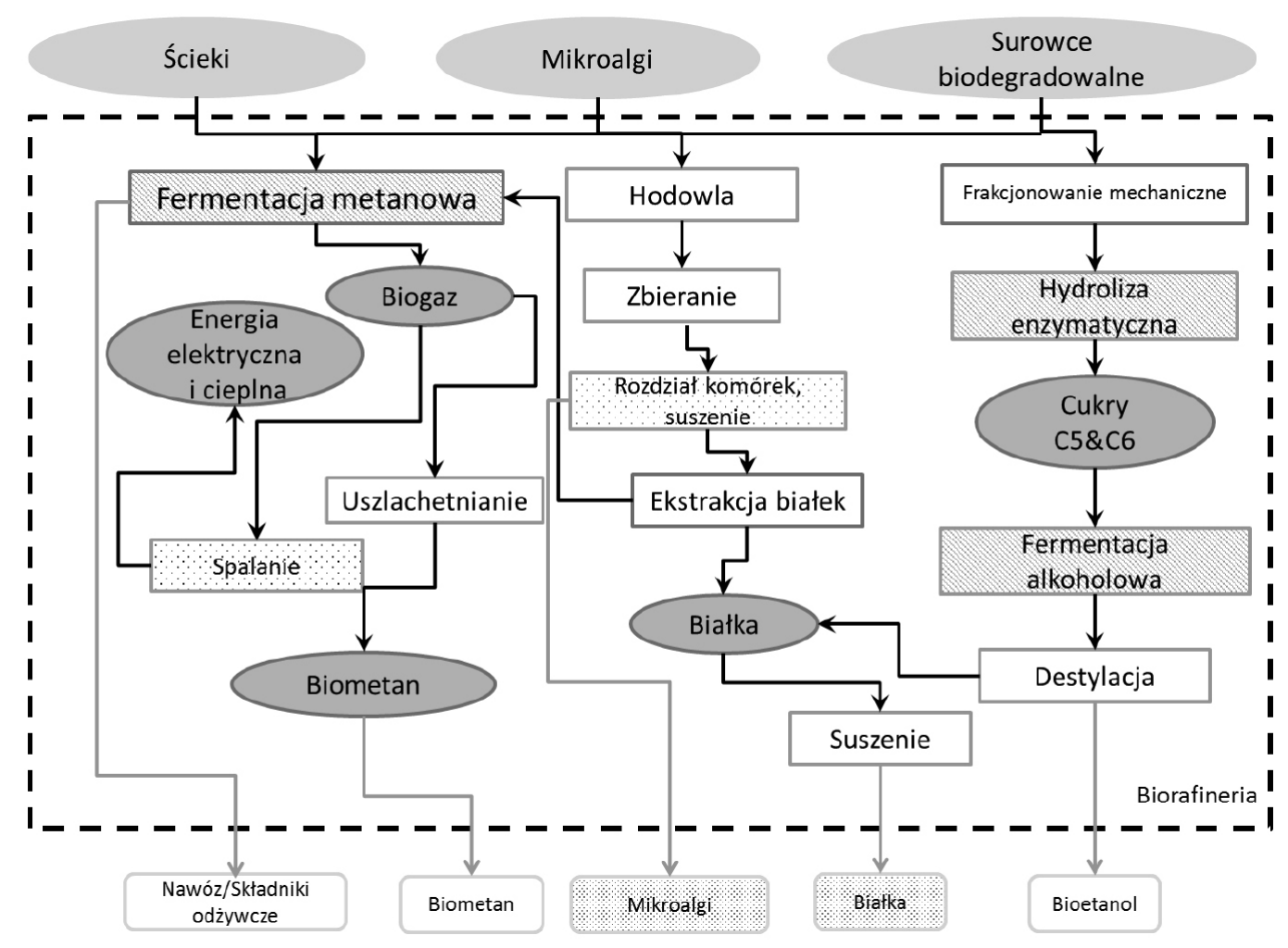

Rys. 8. Pilotażowa biorafineria 5-platformowa w Lelystad w Holandii. Źródło: Jungmeier et al. 2013.

W Lelystad w Holandii uruchomiono pilotażową 5-platformową biorafinerię (rys. 8), która przetwarza ścieki, mikroalgi i inne surowce biodegradowalne. Produktami końcowymi są biogaz, białka, mikroalgi, bioetanol oraz nawóz organiczny. Biorafineria w Lelystad realizuje koncepcję wartości dodanej jaką można uzyskać w wyniku zastosowania procesów biorafinacji oraz ponownego wykorzystania strumieni procesowych, pozostałości, ciepła, $\mathrm{CO}_{2}$ itp. Biorafineria jest układem zintegrowanym $\mathrm{z}$ kilku instalacji: pilotażowa biogazownia, silosy i magazyny pofermentacyjne, pilotażowa instalacja produkcji bioetanolu, instalacja do hydrolizy biomasy lignocelulozowej, instalacja uzdatniania biogazu, systemy produkcyjne dla alg (na otwartych gruntach i w szklarniach), a także użytki rolne do produkcji innej biomasy.

\section{Zasady zrównoważonego rozwoju w biogospodarce}

Nadrzędną zasadą mającą zastosowanie do biogospodarki jest spełnienie zasad zrównoważonego rozwoju. Wyzwaniem pozostaje kwestia precyzyjnego określenia celów, które mają być osiągnięte. Na podstawie europejskiej strategii biogospodarki (B) można zidentyfikować następujące cele szczegółowe: zwiększenie konkurencyjności gospodarki, ograniczenie emisji gazów cieplarnianych, tworzenie nowych miejsc pracy, wsparcie rozwoju obszarów wiejskich, maksymalizację wartości dodanej z jednostki biomasy, ograniczenie zależności od zasobów kopalnych, zwiększenie bezpieczeństwa energetycznego. Określenie celów szczegółowych dla sektora biogospodarki przekłada się na wybór produktów, technologii i łańcuchów wartości, które mają być realizowane. 
Tab. 1. Kryteria zrównoważonego rozwoju i odpowiadające im wskaźniki opisujące biogospodarkę (Źródło: Fritsche et al. 2016: 10-12).

\begin{tabular}{|c|c|c|}
\hline Rodzaj kryterium & Kryteria & Wskaźniki \\
\hline \multirow[t]{15}{*}{ Środowiskowe } & Wykorzystania zasobów & Wykorzystanie gruntów \\
\hline & & Efektywność wykorzystania wtórnych zasobów biomasy' \\
\hline & & Efektywność energetyczna \\
\hline & & Funkcjonalność (jakość usług na wyjściu) \\
\hline & Zmiany klimatu & $\begin{array}{l}\text { Emisje } \mathrm{GHG} \text { w cyklu życia w } \mathrm{CO}_{2 \mathrm{eq}} \text { uwzględniając zmiany użytkowania } \\
\text { gruntu }\end{array}$ \\
\hline & & Inne emisje GHG \\
\hline & $\begin{array}{l}\text { Różnorodność } \\
\text { biologiczna }\end{array}$ & $\begin{array}{l}\text { Obszary chronione i tereny o znacznej wartości różnorodności } \\
\text { biologicznej }\end{array}$ \\
\hline & & Ochrona i zarządzanie różnorodnością biologiczną \\
\hline & Gleba & Erozja \\
\hline & & Węgiel organiczny w glebie \\
\hline & & Równowaga składników pokarmowych w glebie \\
\hline & Woda & Dostępność wody i regionalne oddziaływanie na zasoby wody \\
\hline & & Efektywność wykorzystania zasobów wodnych \\
\hline & & Jakość wody \\
\hline & Powietrze & 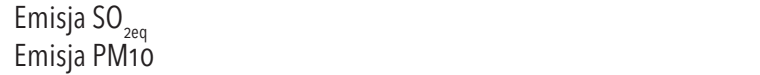 \\
\hline \multirow[t]{10}{*}{ Społeczne } & Udział społeczeństwa & Efektywne procesy partycypacyjne \\
\hline & $\begin{array}{l}\text { i transparentność } \\
\text { informacji }\end{array}$ & Transparentność informacji \\
\hline & Posiadanie gruntów & Zapewnienie prawa posiadania gruntów \\
\hline & $\begin{array}{l}\text { Zatrudnienie i prawa } \\
\text { pracownicze }\end{array}$ & $\begin{array}{l}\text { Ekwiwalent etatów bezpośrednio stworzonych w całym łańcuchu } \\
\text { wartości }\end{array}$ \\
\hline & & $\begin{array}{l}\text { Ekwiwalent etatów bezpośrednio stworzonych w regionie (kraju), } \\
\text { w którym biomasa jest wykorzystywana }\end{array}$ \\
\hline & & Prawa człowieka i prawa pracownicze \\
\hline & & Przepisy BHP \\
\hline & Zdrowie & Ryzyko dla zdrowia publicznego \\
\hline & Żywność i paliwa & Żywność i bezpieczeństwo dostaw żywności \\
\hline & & Paliwa i bezpieczeństwo dostaw paliw \\
\hline \multirow[t]{2}{*}{ Ekonomiczne } & Koszty produkcji & Obecne koszty cyklu życia \\
\hline & & Zaktualizowane przyszłe koszty cyklu życia \\
\hline
\end{tabular}

1 Pozostałości i odpady z procesów przetwarzania biomasy oraz pozostałości i odpady pokonsumpcyjne.

Zasady zrównoważonego rozwoju, kryteria oraz wskaźniki są częścią opracowywanych systemów certyfikacji na kryteria zrównoważonego rozwoju, które dotychczas dotyczyły głównie biopaliw. Komisja Europejska zatwierdziła do dnia dzisiejszego 19 dobrowolnych systemów, które poświadczają, że dana partia biopaliw lub biopłynów spełnia kryteria zrównoważonego rozwoju określone w Dyrektywie 2009/28/WE
(Web-02). Wiele niezależnych systemów certyfikacji zostało stworzonych na potrzeby innych branż, jak np. RSPO (Roundtable on Sustainable Palm Oil) - system odpowiedni dla oleju palmowego lub CoC PEFC (Chain of Custody Certification) - dotyczący wyrobów z drewna.

Dotychczasowe systemy certyfikacji dotyczące biopaliw skupiały się przede wszystkim na środowiskowym wymiarze 
zrównoważonego rozwoju, a właściwie na kilku jego wybranych aspektach - gruntach i emisji GHG. Nie uwzględnia się wielu innych aspektów środowiskowych, takich jak: zużycie wody, efektywne wykorzystanie gruntów, eutrofizacja, zakwaszenie, zubożenie warstwy ozonowej, toksyczność dla człowieka, toksyczność dla środowiska, wytwarzanie odpadów. Takie podejście podyktowane jest brakiem odpowiednich danych, które pozwoliłyby na bardziej kompleksową ocenę danego łańcuch produkcji.

W przypadku zrównoważonej biogospodarki niezbędne jest zastosowanie zintegrowanego podejścia. Chodzi o uchwycenie sensu zrównoważonego rozwoju poprzez zrozumienie relacji i powiązań pomiędzy trzema wymiarami (środowiskowym, społecznym i ekonomicznym) w obszarze ich wzajemnego nakładania się (Wellisch et al. 2010: 283; Mohr i Raman 2013: 115).

W biogospodarce systemy oceny na kryteria zrównoważonego rozwoju muszą odnosić się do wszystkich zastosowań biomasy, uwzględniając szeroki zakres wytwarzanych produktów i ich końcowych zastosowań (biopaliwa, bioenergia i biomateriały). Iriarte i Fritsche (2015: 13-23) zaproponowali podejście parasolowe, stawiając hipotezę, że wszystkie nie-żywnościowe zastosowania biomasy w biogospodarce powinny podlegać ocenie w oparciu o te same kryteria niezależnie od rodzaju surowca i zastosowania końcowego produktu. Zaproponowali zestaw kryteriów i wskaźników na tzw. etapie pośrednim, z których mogą być wyprowadzone wskaźniki szczegółowe odnoszące się do specyficznych surowców i zastosowań produktów końcowych. Łącznie uwzględniono 12 kryteriów i 27 wskaźników, które mogą być zastosowane do oceny nie-żywnościowych łańcuchów wartości, patrz tab. 1.

Ocena na kryteria zrównoważonego rozwoju może dotyczyć konkretnych łańcuchów wartości opartych na zasobach biomasy bądź konkretnej biorafinerii (Wellisch et.al 2010: 283). Niezbędne jest opracowanie wskaźników szczegółowych, wartości progowych i narzędzi, które będą mogły być stosowane dla oceny poszczegółowych łańcuchów wartości w biogospodarce lub biorafinerii, tak aby dać odpowiedź czy spełnione są zasady zrównoważonego rozwoju oraz postawione cele.

\section{Podsumowanie}

Biogospodarka obejmuje wszystkie działy gospodarki związane z produkcją zasobów pochodzenia biologicznego oraz przetwarzaniem tych zasobów na produkty, takie jak na przykład biopaliwa. Biopaliwa są pierwszym produktem biogospodarki, dla którego wyznaczono obowiązkowe cele ilościowe w rynku. Jednocześnie biopaliwa są jak dotąd jedynym rodzajem produkcji przemysłowej, która została obłożona obowiązkiem certyfikacji na zgodność z kryteriami zrównoważonego rozwoju. Uzasadnione jest twierdzenie, że podobne wymagania mogą mieć w przyszłości zastosowanie dla innych produktów biogospodarki. Odejście od produkcji biopaliw wytworzonych z surowców spożywczych i paszowych na rzecz zwiększonego wykorzystania biopaliw zaawansowanych służy racjonalizacji wykorzystania zasobów biomasy w biogospodarce. W praktyce oznacza to skierowanie strumienia biomasy pierwotnej głównie do produkcji żywności oraz biomateriałów i bioproduktów o wysokiej wartości rynkowej, przeznaczając pozostałości i odpady na potrzeby sektora bioenergii i biopaliw. W piramidzie wartości opisującej biogospodarkę biopaliwa są kategorią produktów, które leżą u podstawy - powinny być relatywnie tanie i produkowane masowo.

\section{Bibliografia}

Biernat K., Grzelak P.L., 2015, Biorefinery Systems as an Element of Sustainable Development, Biofuels Status and Perspective, INTECH.

Borychowski M. 2014, Produkcja biopaliw w Polsce a zrównoważony rozwój rolnictwa. Dylemat biogospodarki, Stowarzyszenie Ekonomistów Rolnictwa i Agrobiznesu, Roczniki Naukowe, vol. XVI (6), p. 51-56.

Budzianowski W., 2017, High-value low-volume bioproducts coupled to bioenergies with potential 
to enhance business development of sustainable biorefineries, Renewable and Sustainable Energy Reviews, vol. 70, 793-804.

EBTP SRIA 2016, Strategic Research and Innovation Agenda 2016, Innovation driving sustainable biofuels, European Biofuels Technology Platform, June 2016.

Fritsche U.F., Iriarte L., Lindner M., Fitzgerald J. Panoutsou P., 2016, Guidelines on assessing bioeconomy value chain sustainability performance, Deliverable 5.5 S2Biom Project Grant Agreement no608622, http://www.s2biom.eu/images/Publications/D5.5_S2Biom_Guidelines.pdf, dostęp 15.3.2017.

Gołebiewski J., 2013, Zrównoważona biogospodarkapotencjat i czynniki rozwoju, IX Kongres Ekonomistów Polskich, Warszawa, 28-29 listopada 2013 r.

GUS 2015, Energia ze źródeł odnawialnych $w 2015 r$., Główny Urząd Statystyczny, Warszawa.

IEA Bioenergy 2014, Sustainable and synergetic processing of biomass into marketable food $\mathcal{E}$ feed ingredients, chemicals, materials and energy (fuels, power, heat), IEA Bioenergy - Task 42 Biorefining http://edepot.wur.nl/313931, dostęp 15.3.2017.

IRENA 2016, Innovation Outlook, Advanced Liquid Biofuels, Summary for policy makers, International Renewable Energy Agency, ISBN 978-92-95111-38-7. Iriarte L., Fritsche U., 2015, Consistent Cross - Sectoral Sustainability Criteria E Indicators, Deliverable 5.4. S2Biom Project Grant Agreement no608622, http://www.s2biom.eu/images/Publications/IINAS_2015_S2Biom_D5_4_Sustainability_C_I_proposal_Main_report_3o_Mar.pdf, dostęp 15.3.2017.

Jungmeier G., Hingsamer M., van Ree R., 2013, Biofuel-driven biorefineries: a selection of the most promissing biorefinery concepts to produce large volumes of road transportation biofuels by 2025, IEA Bioenergy - Task 42 Biorefining.

Owczuk, M., Rogulska M., Bogumił D., Biernat K., 2015, Perspektywy rozwoju technologii biorafineryjnych, Chemik, vol. 69, 749-758.

Scarlat N., Dallemand J.F., Monforti-Ferrario F., Nita V., 2015, The role of biomass and bioenergy in a future bioeconomy: Policies and facts, Environmental Development, vol. 15, 3-34.

Szwach R., Kulesza R., 2014, Potencjat biomasy $w$ aspekcie otrzymywania wybranych surowców i produktów chemicznych, Chemik vol. 68, 893-900. van Ree R., 2016, Integration of Advanced Biofuels in Circular Economy, Identifying major innovation options, European Biofuel Technology Platform, 7th Stakeholder Plenary Meeting, Brussels, 21.06.2016.

Wellisch M., Jungmeier G., Karbowski A., Patel M.K., Rogulska M., 2010, Biorefinery systems - potential contributors to sustainable innovation, Biofuels Bioproducts \& Biorefining, vol. 4, 275-286.

Web-o1: Pakiet Zimowy "Czysta energia dla wszystkich Europejczyków”: http://ec.europa.eu/energy/ en/news/commission-proposes-new-rules-consumer-centred-clean-energy-transition, dostęp 20.3.2017.

Web-o2: Dobrowolne systemy certyfikacji biopaliw i biopłynów na kryteria zrównoważonego rozwoju: https://ec.europa.eu/energy/en/topics/ renewable-energy/biofuels/voluntary-schemes, dostęp 15.3.2017.

\section{Akty prawne}

A: Komunikat Komisji. EUROPA 2020: Strategia na rzecz inteligentnego i zrównoważonego rozwoju sprzyjającego włączeniu społecznemu. Bruksela, 3.3.2010 r. (KOM(2010) 2020 wersja ostateczna).

B: Komunikat Komisji do Parlamentu Europejskiego, Rady, Europejskiego Komitetu Ekonomiczno-społecznego i Komitetu Regionów „Innowacje w służbie zrównoważonego wzrostu: biogospodarka dla Europy. Komisja Europejska, Bruksela, dnia 13.2.2012 r. (COM(2012) 6o final).

C: Dyrektywa 2003/30/WE Parlamentu Europejskiego i Rady z dnia 8 maja 2003 r. w sprawie wspierania użycia $w$ transporcie biopaliw lub innych paliw odnawialnych. (Dz.U. UE L 123, 17.5.2003, p. 42-46).

D: Dyrektywa Parlamentu Europejskiego i Rady 2009/28/WE z dnia 23 kwietnia 2009 r. w sprawie promowania stosowania energii ze źródeł odnawialnych zmieniająca i w następstwie uchylająca dyrektywy 2001/77/WE oraz 2003/30/WE. (Dz.U. UE L 09.140.16).

E: Wniosek: Dyrektywa Parlamentu Europejskiego i Rady w sprawie promowania energii ze źródeł odnawialnych (wersja przekształcona). Bruksela, dnia 22.2.2017 r. (COM/2016/0767 final - 2016/0382 (COD).

F: Dyrektywa Parlamentu Europejskiego i Rady 2015/1513 z dnia 9 września 2015 r. zmieniająca 
dyrektywę 98/70/WE odnoszącą się do jakości benzyny i olejów napędowych oraz zmieniająca dyrektywę 2009/28/WE w sprawie promowania stosowania energii ze źródeł odnawialnych. (Dz.U. UE L 15.9.2015, p.1-29).

G: Aneksy 1-12 do (E) Wniosku: Dyrektywa Parlamentu Europejskiego i Rady w sprawie promowania energii ze źródeł odnawialnych (wersja przekształcona). Bruksela, dnia 23.2.2017 r. (COM(2017) 767 final/2 ANNEXES 1 to 12).
H: Opinia Europejskiego Komitetu Ekonomiczno-Społecznego w sprawie wkładu przemysłu drzewnego w bilans dwutlenku węgla. Bruksela, dnia 10 grudnia 2014 r. (2015/C 230/o6) (Dz.U. UE L 14.7.2015, p. 39-46).

\section{Biofuels in sustainable bioeconomy}

\section{Summary}

Transportation biofuels have been promoted by supportive policies and initially get public acceptance. However, over time many negative consequences raised controversies over conventional biofuels produced from food and feed crops. Advanced biofuels from feedstock not competing with food production are expected to have an important role in the new bioeconomy sector based on a sustainable biomass production and conversion into a wide spectrum of added value products. Biofuels should be mainly produced from wastes and residues. Biorefineries producing biofuels and bioproducts have a critical role in the industrial production of sustainable bioeconomy.

\section{Key words}

biofuels, bioenergy, biorefinery, bioeconomy, sustainability criteria 